\title{
A proposal on a new curriculum for the smart eco-efficient built environment
}

\author{
F.Pacheco Torgal \\ C-TAC Research Centre, University of Minho, Portugal
}

\begin{abstract}
Several authors reported a severe reduction in undergraduate applications to civil engineering in different countries. This fact will lead to a severe shortage of civil engineers in the coming years. These professionals will be especially needed to tackle infrastructure construction and rehabilitation on a context of climate change and increased world population. Part of the explanation for the low attraction capability of civil engineering relates to the fact that this course is viewed as low tech. A scientific and technical upgrade of the civil engineering curriculum is, therefore, needed. Nano and biotech based materials and technologies for the built environment could refresh the attraction of this area. The environmental challenges faced by a Planet that has about 220,000 new inhabitants each day and that will have more than 9,7 billion people by 2050 and 11,2 billion by 2100 means that a strong eco-efficiency focus of the new curriculum is also needed. On this context a proposal on a new curriculum on Smart Eco-Efficient Built Environment is suggested that could provide the construction market with professionals with a set of new and enhanced holistic high tech skills.
\end{abstract}

\section{INTRODUCTION}

In UK several authors (Byfield, 2001; Edwards et al., 2004) have reported a worrying reduction on applications to civil engineering. Other countries face similar problems (Lawless, 2005; Hubbard and Hubbard (2009).

Quapp and Holschemacher (2013) mentioned that in German almost $50 \%$ of civil engineer student's drop out aggravating the shortage of civil engineers. India is also facing a severe shortage of civil engineers to achieve its huge infrastructural development targets. Again, as it happens in the US, the demand is not the problem (construction industry in India needs civil engineers). This reason, however, however seems insufficient to motivate Indian students. Part of the explanation for the low attraction capability of civil engineering relates to the fact that, in India this course is viewed as "brick and mortar engineering" (Chakraborty et al., 2011).

The fact that construction enterprises has low productivity (Fulford e Standing, 2014) and compete for lower bids having lower and lower profit margins (Morby, 2014) means that construction enterprises will in future have less and less financial possibilities to offer high and attracting pay checks to civil engineers. This of course will contribute to a decrease in civil engineering applications. Also civil engineering was never known to be associated with high tech startup creation. This is a sign of the low innovation level which is confirmed by its low patenting level. In the US the patenting level on civil engineering falls behind other areas (Rothe, 2006).

According to Keefe (2012) very few civil engineers take their innovations to the United States Patent and Trademark Office (USPTO), in contrast to the considerable number of electrical and mechanical engineers. This low innovation level undermines the prestige of civil engineering and contributes to explain the reduction on undergraduate applications.

The solution for this will require important changes in the civil engineering curriculum. This paper analyses relevant issues regarding the ecoefficiency of the smart built environment and how they can be incorporated into an updated civil engineering curriculum.

\section{SUSTAINABLE DEVELOPMENT CONSIDERATIONS}

One of the oddest features of the humankind is the fact that it uses a huge amount of resources, including non-renewable ones, leaving traces of pollution in the consumption process. This is worsen by the fact that about 220,000 new inhabitants are born 
each day on planet Earth and will soon reach 9700 million by 2050 and 11000 by 2100 (UN, 2015).

A new approach to global sustainability was proposed by Rockstrom et al (2009). This author suggested nine interdependent planetary boundaries within which they expect that humanity can operate safely. Unfortunately and strange it maybe humanity has already transgressed three planetary boundaries. During the last century, materials use increased 8fold and, as a result, humanity currently uses almost 10 billion $\left(10^{10}\right)$ tonnes of engineering materials per year and since materials demand will double in the next 40 years, the environmental impacts will therefore increase in a drastic manner (Krausmann et al., 2009; Allwood et al., 2011; Ashby, 2015).

The global construction industry consumes more raw materials (about $3000 \mathrm{Mt} / \mathrm{year}$, almost $50 \%$ by weight) than any other economic activity, which emphasizes its unsustainable character. Also, in the next years the construction industry will keep on growing at a fast pace. China will need 40 billion square meters of combined residential and commercial floor space over the next 20 years - equivalent to adding one New York City every two years (Pacheco-Torgal and Jalali, 2011).

Unfortunately, sustainable development principles have not yet been apprehended by University curricula (especially in the case of the construction sector). It is a fact that, in recent years, several authors theorized about the way to embed sustainable development in higher education and several institutions made some efforts on this issue (Lozano, 2006; Holmberg et al., 2008; De Vere et al., 2009; Lozano, 2010; Waheed et al., 2011). However, it seems that this is not the most effective approach. As PachecoTorgal and Jalali (2007) put it, the fact that the awareness to sustainability issues raised in a few dispersed lectures is not the same as to change an entire curriculum with an integrated vision on this matter. As a result, the validation of any discipline in any engineering curriculum must be put to a test in which the one million dollar question is "How can your discipline contribute to sustainable development?" (Salcedo-Rahola and Mulder, 2009). Therefore, concerning the civil engineering curriculum, it is important that the revised curriculum displays a strong commitment to sustainable development principles.

\section{NANOTECHNOLOGY OPPORTUNITIES FOR ECO-EFFICIENT BUILT ENVIRONMENT}

Zheng et al. (2011) stated that nanotechnology could help to convey a new vision for civil engineering. This a hot area with an amazing growth potential. Very few nanotech applications are currently in use in the construction sector which, in fact, seems to have been somewhat neglected by nanotech research to date (Pacheco-Torgal and Jalali, 2011a; PachecoTorgal et al., 2012).

Building energy efficiency is an issue of crucial importance for which nanotechnology could bring important improvements. The global market for energy efficient building will go from 68 billion dollars in 2011 to surpassing 100 billion dollars by 2017 . The recasting of the Energy Performance of Buildings Directive (EPBD) was adopted by the European Parliament and the Council of the European Union on 19 May 2010. The recast set 2020 as the deadline for all new buildings to be 'nearly zero energy'; for public buildings, however, the deadline is even sooner - the end of 2018.

High performance thermal insulator materials are consequently deemed necessary to achieve such targets. Aerogel is a perfect example of a high performance nanotech based thermal insulation material Jelle (2011). Recent investigations show promising energy efficiency results regarding the use of aerogel based materials (Filate, 2014; Buratti et al., 2014). Since the majority of energy losses in a building occur through windows the improvements of windows thermal performance is crucial for building energy efficiency. Aerogel based windows constitute very promising high tech alternatives. Buratti and Moretti (2013) compared the performance of seven different glazings and found that granular aerogel glazing was the most efficient systems especially for cold climates leading to an annual energy demand decreases of about $10-20 \%$ when compared to the standard glazings. However, the eco-efficiency of aerogel windows still remains to be proven by life cycle assessment investigations.

Another important nanotech research line concerns the development of cool materials incorporating new advanced nano-materials (Santamouris et al., 2011). Cool materials have high solar reflectance (high albedo or low emissivity) allowing for the reduction of energy cooling needs in Summer. The Cool-Coverings FP7 project (Escribano et al.,, 2013) which aim to the development of a novel and costeffective range of nanotech improved coatings to substantially improve near infrared reflective properties constitutes a very interesting ground for the creation of startups.

Also crucial is switchable glazing technology based materials. This refers to "materials and devices that make it possible to construct glazings whose throughput of visible light and solar energy can be switched to different levels depending on the application of a low DC voltage (electrochromics) or on the temperature (thermochromics) or even by using hydrogen (gasochromics). Electrochromic windows have shown a 54\% energy reduction in electrochromic windows when compared to standard single glazed windows for a 25 years life cycle (Pa- 
paefthimiou et al., 2006). Other authors (Yoshimura et al., 2009) studied gasochromics windows reporting a 34\% reduction on cooling needs when compared to standard double glazed windows.

The most challenging point of smart windows at the moment is their higher cost compared to the other glazing technologies (Cuce and Riffat, 2015. However, it is expected that in the next years, a higher performance and lower cost switchable glazing windows will be available.

\section{BIOTECHNOLOGIES FOR ECO-EFFICIENT BUILT ENVIRONMENT}

Biotechnology is one of the world's fastest growing industries. As such, it could constitute, in the future, a hot area allowing for radical changes in the eco-efficiency of construction materials and technologies. Since biotechnology is one of one of the six Key Enabling Technologies-KETs that will be funded under the EU Framework Programme Horizon 2020 (Pacheco-Torgal, 2014) this can also foster the development of start-ups in the field of bio materials and technologies for the eco-efficient built environment.

These may include the use of admixtures based on renewable bio-based feedstock's and or capable of biodegradation to replace chemical admixtures used in Portland cement concrete. Examples of biopolymers used in concrete include for instance lignosulfonate, pine root extract, protein hydrolysates or even vegetable oils. Biotechnological admixtures processes made in fermentation processes by using bacteria or fungi are seem receiving increased attention. This includes sodium gluconate, curdlan or Welan gum (Planck, 2004, 2005).

However, farming practices used to grow bio based feedstocks including the fuel required for plowing, harvesting, manufacture, transport and the use of herbicides and pesticides can also have high environmental impacts as high of petrochemical based polymers (la Rosa, 2015). The use of alternative feedstocks, which might be either waste- or byproducts or less energy and chemical intensive crops will improve its overall environmental performance (Koutinas et al., 2014). Investigations on cellulose nanocrystals (cellulose elements having at least one dimension in the 1-100nm range) constitute an important biotech feature for building energy efficiency (Charreau et al., 2013; Chivaril et al., 2014; Chen et al., 2014).

Another important biotech feature for ecoefficient built environment concerns the production of bio-energy trough microalgae. Photosynthetic microalgae use sunlight as their energy, water as their electron source and $\mathrm{CO}_{2}$ as carbon source. The use of microalgae for biofuel production goes back to the 80's (Chisti, 1980) and has gained increased attention due to the need of renewable energies. Architectural Photo-Bioreactors, are photo-bioreactors similar to the industrial ones, and in the same way, fulfil the functioning of cultivating microalgae, the innovation is its integration into architecture. The synergy generated by summation "profits" turn the architecture into iconic, environmentally didactic, active energetically, surface saving and environmentally friendly, all with minimal increase of their cost, that is, with very low investment and high returns (Cervera and Pioz, 2014). Although more investigations are needed to optimize this technique it has high potential for startup creation for the energy efficient built environment.

\section{FOCUS ON HOME USER'S PROBLEMS}

This author believes that first and foremost civil engineering should focus on individual home user's needs just because different users have different problems thus needing millions of tailored solutions. This represents a market of millions of clients that could help fostering startup creation. In that context it is important to review home users comfort related issues that need to address and may constitute business opportunities to the built environment professionals.

The importance of light for a heath human condition is a recent discovery with the potential to have a major impact on built environment design. Light has circadian, neuroendocrine and neurobehavior effects. Light has a relevant role in improving behaviour, sleep and circadian rhythmicity of older people affected by diseases such as dementia and Alzheimer (Van Hoof et al., 2009; Dowling et al., 2005). This an important issue because Europe a large number of older people live in old buildings that are exposed to insufficient daylight exposure and this group will increase in the next decades. In most countries the requirements associated with daylight are based only on minimum window size as a percentage of floor area or of wall area, i.e. they don't guarantee enough daylight in concrete interiors in real urban patterns (Hraska, 2015).

Another important problem is related to users behaviour concerns building energy consumption prediction because most often it assumes a standard use of the buildings and underestimates the real building energy consumption (Bonte et al., 2014). This gap can be as much as of 2.5 the predicted energy use (Menezes et al., 2012; De Wilde, 2014). Such difference is related to occupant's behaviour that strongly influence the building energy consumption. Yang et al (2014) provides a review on the influence of thermal comfort and building energy consumption including the importance of socio-economic and cultural issues. Thus being able to conveniently adapt a 
building to its occupants ensures a better indoors working and living environment. This means that building design must be dynamic enough to fit occupants with different consumption patterns and that adaptation will require tailor made solutions capable of creating new business opportunities to the built environment professionals.

Smart home solutions especially for users with special needs are another important area that may unleash a lot of business opportunities for to the built environment professionals. According to De Silva et al (2012) the investigation on smart homes begun in 90s with the MIT pioneering work "Smart rooms" (Pentland, 1996). Other authors (Wong et al., 2005) mentioned that Intelligent Buildings started three decades ago. For this author Intelligent Buildings not only are responsive to the occupants needs but at the same time are sustainable in terms of energy and water consumption and maintains a minimal impact of the environment in terms of emissions and waste including the use of self-healing and smart materials technology (Clements-Croome, 2011). The concept "smart buildings" have been associated with a more recent and advanced grouping (Buckman et al., 2014) that integrate and account for intelligence, enterprise, control, and materials and construction as an entire building system, with adaptability, not reactivity, at its core, in order to meet the drivers for building progression: energy and efficiency, longevity, and comfort and satisfaction.

\section{A PROPOSALFOR A NEW CURRICULUM ON SMART ECO-EFFICIENT BUILT ENVIRONMENT}

Taking into consideration what was previously wrote and using the prestige civil engineering curriculum at the Imperial College London (ICL) as base a proposal for a new curriculum on smart ecoefficient built environment is suggested. In order to design the new curriculum 15 new core modulus are incorporated on ICLs existent civil engineering MEng curriculum (Table 1).

Given the importance of eco-efficient construction materials two new modules on this issue are to included respectively in the first and on the second year. This option recognizes the increased importance of materials for the construction industry as well of its major environmental impacts. A module on biology and biotechnology basics is included on the first year while a module on microbiology is suggested for the second year. This will help future practitioners of the construction industry to understand the language of their fellow colleagues from while a module on nano and biotech applications is to be included in the third year.
Table 1. Current Civil Engineering Meng curriculum at the Imperial College London (ICL) and suggested core modulus for a curriculum on Smart Eco-Efficient Built Environment

\begin{tabular}{|c|c|}
\hline $\begin{array}{l}\text { Existent core modules } \\
\text { at the Civil Engineering } \\
\text { at ICL }\end{array}$ & $\begin{array}{l}\text { Suggested core modules for } \\
\text { a eco-efficient built envi- } \\
\text { ronment undergraduated } \\
\text { curriculum }\end{array}$ \\
\hline Year 1 & Year 1 \\
\hline Professional Engineering & Professional Engineering Prac- \\
\hline Practice & tice \\
\hline Drawing & Drawing \\
\hline Surveying & Creative Design 1 \\
\hline Creative Design 1 & Mat. for eco-efficient con- \\
\hline Materials & struction 1 (New) \\
\hline Mechanics & Mechanics \\
\hline Structural Mechanics & Structural Mechanics \\
\hline Fluid Mechanics & Fluid Mechanics \\
\hline Geotechnics & Mathematics \\
\hline Mathematics & Computational Methods I \\
\hline Environmental Engineer- & Nanotechnology basics (New) \\
\hline ing Science & Biol. and biotech. basics \\
\hline Computational Methods I & (New) \\
\hline Energy \& Infrastructure I & Smart built environment eco- \\
\hline Introduction to Civil En- & efficiency (New) \\
\hline gineering & Entrepreneurship skills (New) \\
\hline Year 2 & Humanities/SS (New) \\
\hline Creative Design II & Year 2 \\
\hline Fluid Mechanics & Structural Mechanics \\
\hline Structural Mechanics & Soils and Engineering Geolo- \\
\hline Soils and Engineering Ge- & gy \\
\hline ology & Statistics \\
\hline Environmental Engineer- & Mathematics \\
\hline & Computational Methods II \\
\hline Statistics & Structural Design \\
\hline Mathematics & Fluids Design \\
\hline Computational Methods II & Materials for eco-efficient \\
\hline Structural Design & construction 2 (New) \\
\hline Fluids Design & Circular economy and life cy- \\
\hline Project \& Business Man- & cle analysis (New) \\
\hline agement & Microbiology (New) \\
\hline Year 3 & Humanities and social sciences \\
\hline Structure and Geotechnics & (New) \\
\hline Projects & Year 3 \\
\hline Structural Mechanics & Structure and Geotechnics \\
\hline Fluid Mechanics & Projects \\
\hline Transport Systems & Computational Engineering \\
\hline Environmental Engineer- & Analysis \\
\hline & Apps for the smart built envi- \\
\hline Geotechnics & ronment (New) \\
\hline $\begin{array}{l}\text { Computational Engineer- } \\
\text { ing Analysis }\end{array}$ & Low carbon build. design \\
\hline Dynamics & Biomimetics and bioinspired \\
\hline Optional 1 & design $(\mathrm{New})$ \\
\hline Optional 2 & Nano and biotech applications \\
\hline The year ends with a five- & (New) \\
\hline week group design project. & Humanities/SS (New) \\
\hline Year 4 & Start-up creation and Business \\
\hline Core modules & Management \\
\hline Individual Research Pro- & Optional 1 \\
\hline ject & Optional 2 \\
\hline Student Conference (Final & The year ends with a five- \\
\hline $\begin{array}{l}\text { Activity) } \\
\text { Optional modules }\end{array}$ & $\begin{array}{l}\text { week group design project. } \\
\text { Year } 4\end{array}$ \\
\hline 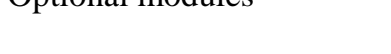 & Core modules \\
\hline & Individual Research Project \\
\hline & Student Conference \\
\hline & Optional modules \\
\hline
\end{tabular}


biology and enhance future collaborations between the two areas. A module on nanotech basics is also to be included on the first year of the new curriculum The smart eco-efficiency of the built environment merits the inclusion of one module in the first year, a module on the section year related to the circular economy and life cycle analysis (Pacheco-Torgal, 2013). The inclusion of module o the third year related to low carbon building design will allow the fulfillment of nearly zero energy building targets (Pacheco-Torgal et al., 2013a). The inclusion of a module on entrepreneurship is needed because it is crucial for startup creation. In the current context of young high-educated high unemployment rates that will be more dramatic in the next decades, startup creation could become a way to solve this serious problem. The development of apps for the smart built environment merits the inclusion of a new module on the third year. This could become a key skill for practitioners of the construction industry and a startup creation trigger. Three modules on humanities and social sciences are also included in the new curriculum. Social related skills are of paramount importance in future civil engineering curriculum. Humanities knowledge is especially needed because it is literature, especially in the form of novel and tragedy, which highlights how people cope with ethical dilemmas. This is especially important in the context of climate change which raises many questions with ethical dimensions rooted in the human condition.

\section{CONCLUSIONS}

In order to propose a new curriculum this paper reviews related literature. Nano and biotech opportunities are highlighted. Issues related to indoors working and living conditions as well as smart homes features are also reviewed. The new program is not meant to replace the civil engineering curriculum. It is rather obvious that the civil engineering curriculum, as we know it will continue to exist in the next decades. On one hand, some countries do not have a civil engineering curriculum demand problem, at least not yet. As a consequence, they haven't the necessary drive to operate radical changes on it. On the other hand, because civil engineering relies heavily on standards, and so far, standards on nano and biotechnologies for the construction industry do not exist. However, the time has come to discuss an alternative curriculum.

\section{REFERENCES}

Allwood, J., Ashby, M., Gutowski, T. \& Worrell, E. 2011. Material efficiency: A white paper. Resources, Conservation and Recycling 55, 362-381.
Ashby, F. 2015. Materials and sustainable development. First edition Butterworth-Heinemann, Elsevier, Oxford, UK

Byfield, M.P. 2001. Graduate shortage: The key to civil engineering's future? Proceedings of the Institution of Civil Engineers: Civil Engineering 144 (4), pp. 161-165

Bonte, M., Thellier, F. \& Lartigue, B. 2014. Impact of occupant's actions on energy building performance and thermal sensation. Energy and Buildings 76, 219-227.

Buckman A., Mayfield, M. \& Beck, S. 2014. "What is a Smart Building?", Smart and Sustainable Built Environment, Vol. 3 Issue 2 pp. $92-109$.

Buratti, C. \& Moretti, E. 2013. Chapter 20 -Nanogel windows. In: Torgal FP, Mistretta M, Kaklauskas A, Granqvist CG, Cabeza LF (ed) Nearly Zero Energy Building Refurbishment: A Multidisciplinary Approach, Springer-Verlag London Ltd.

Cervera, R. \& Pioz, J. 2014 Architectural bio-photo reactors: Harvesting microalgae on the surface of architecture. 163180, In Biotechnologies and Biomimetics for Civil Engineering, Eds Pacheco-Torgal, F.; Labrincha, J.; Diamanti, M.; Yu, C.-P.; Lee, H.K., Springer, London

Chakraborty, S., Iyer, N., Krishna, P. \& Thakkar, S. 2011. Assessment of Civil Engineering Inputs for Infrastructure Development. Indian National Academy of Engineering.http://www.inae.org/research_studies_civil_engineering. html

Charreau, H., Foresti, M. \& Vazquez, A. 2013. Nanocellulose patents trends: A comprehensive review on patents on cellulose nanocrystals, microfibrillated and bacterial cellulose. Recent Patents on Nanotechnology vol. 7, 56-80.

Chirayil, C., Mathew, L. \& Thomas, S. 2014. Review of recent research in nanocellulose preparation from different lignocellulosic fibers. Rev Adv Mater Sci 37, 20-28.

Chen, W., Li, Q., Wang, Y., Yi, X., Zeng, J., Yu, H., Liu, Y. \& Li, J. 2014. Comparative study of aerogels obtained from differently prepared nanocellulose fibers. ChemSusChem 7, 154-161.

Chisti, Y. 1980. An unsual hydrocarbon. J Ramsay Soc 27-28, 24-26.

Clements-Croome, D. 2011. Sustainable intelligent buildings for people: A review. Intelligent Buildings International 3, 67-86.

Cuce, E. \& Riffat, S. 2015. A state-of-the-art review on innovative glazing technologies. Renewable and Sustainable Energy Reviews 41, 695-714.

De Silva, L., Morikawa, C. \& Petra, I. 2012. State of the art of smart homes. Engineering Applications of Artificial Intelligence 25, 1313-1321.

De Vere, I., Bissett Johnson, K. \& Thong, C. (2009) Educating the responsible engineer: socially responsible design and sustainability in the curriculum. EPDE09/134, International conference on engineering and product design education, 10 \& 11 September 2009, University of Brighton, UK

De Wilde, P. 2014. The gap between predicted and measured energy performance of buildings: A framework for investigation. Automation in Construction 41, 40-49.

Dowling, G.A., Hubbard, E.M., Mastick, J., Luxenberg, J.S., Burr, R.L.\& Van Someren, E.J. 2005. Effect of morning bright light treatment for rest-activity disruption in institutionalized patients with severe Alzheimer's disease. International Psychogeriatrics 17(2):221-36.

Escribano, M. \& Keraben Grupo SA. 2013. Development of a novel and cost-effective range of nanotech improved coatings to substantially improve NIR (Near Infrared Reflective) properties of the building envelope, FP7 Project http://cordis.europa.eu/project/rcn/94644_en.html

Fulford, R. \& Standing, C. 2014. Construction industry productivity and the potential for colaborative practice. International Journal of Project Management 32, 2, 315-326 
Hraska, J. 2015 Chronobiological aspects of green buildings daylighting. Renewable Energy 73 (2015) 109-114.

Holmberg, J., Svanström, M., Peet, D.J., Mulder, K., FerrerBalas, D. \& Segalàs, J. 2008. Embedding sustainability in higher education through interaction with lecturers: Case studies from three European technical universities. European Journal of Engineering Education, 33 (3), pp. 271-282

Hubbard, B.J. \& Hubbard, S.M. 2009. Activities to enhance civil engineering recruitment and coordination with industry. Transportation Research Record, 22-30.

Yang, L., Yan, H. \& Lam, J. 2014. Thermal comfort and building energy consumption implications $-\mathrm{A}$ review. Applied Energy 115, 164-173.

Yoshimura, K., Yamada, Y., Bao, S., Tajima, K. \& Okada, M. 2009. Preparation and characterization of gasochromic switchable-mirror window with practical size. Solar Energy Materials \& Solar Cells, 2138-2142.

Jelle, B. 2011. Traditional, state-of-the-art and future thermal building insulation materials and solutions - Properties, requirements and possibilities. Energy and Buildings 43, 2549-2563.

Keefe, S. 2012. Patent eligibility: An open field for civil engineering. Civil Engineering 70-73.

Koutinas, A., Vlysidis, A., Pleissner, D., Kopsahelis, N., Garcia, I., Kookos, I., Papanikolaou, S., Kwan, T. \& Lin, C. 2014. Valorization of industrial waste and by-product streams via fermentation for the production of chemicals and biopolymers. Chemical Society Reviews 43, 25872627.

Krausmann, F., Gingrich, S., Eisenmenger, N., Erb, K.-H., Haberl, H. \& Fischer-Kowalski, M. 2009. Growth in global materials use, GDP and population during the 20th century. Ecological Economics 68, 2696-2705.

la Rosa, A. D. 2015. LCA of biopolymers. in: Pacheco-Torgal, F; Ivanov, V.; Karak, N.; de Jonkers, H. (eds) Biopolymers and biotech admixtures for eco-efficient construction materials., Woodhead, Cambridge, UK

Lawless, A. 2005. A wake up call to address the capacity crisis in SA civil engineering. Civil Engineering/Siviele Ingenieurswese 13 (10), 40-43.

Lozano, R. 2006. Incorporation and institutionalization of SD into universities: breaking through barriers to change. Journal of Cleaner Production, 14 (9-11), pp. 787-796

Lozano, R. 2010. Diffusion of sustainable development in universities' curricula: an empirical example from Cardiff University. Journal of Cleaner Production, 18 (7), pp. 637-644.

Menezes, A., Cripps, A., Bouchlaghem, D., Buswell, R. 2012. Predicted vs. actual energy performance of non-domestic buildings: Using post-occupancy evaluation data to reduce the performance gap. Applied Energy 97, 355-364.

Morby, A. 2014. Cost rises squeeze builders profit margins. Construction enquirer, 10 of February

Pacheco-Torgal, F. 2014. Eco-efficient construction and building materials research under the EU Framework Programme Horizon 2020. Construction and Building Materials Vol.51, 151-162.

Pacheco-Torgal, F., Cabeza, L., Labrincha, J. \& Magalhães, A. 2013. Eco-efficient construction and building materials: Life cycle assessment, eco-labelling and case studies. Woodhead Publishing Limited Abington Hall, Cambridge, UK

Pacheco-Torgal, F., Cabeza, L., Mistretta, M., Kaklauskas, A. \& Granqvist, C.G (2013a) Nearly zero energy building refurbishment. A multidisciplinary approach Springer Verlag, London, UK.

Pacheco-Torgal, F., Diamanti, M., Nazari, A. \& Granqvist, C.G. 2012. Nanotechnology in eco-efficient construction. Materials, processes and applications. Woodhead Publishing Limited Abington Hall, Cambridge, UK
Pacheco-Torgal, F. \& Jalali, S. 2011a. Nanotechnology: Advantages and drawbacks in the field of building materials. Construction and Building Materials Vol.25, 582-590.

Pacheco-Torgal, F. \& Jalali, S. 2011. Eco-efficient construction and building materials. Springer Verlag, London, UK.

Pacheco-Torgal, F. \& Jalali, S. 2007. Does engineering students need sustainable development courses? ICEE 2007 International Conference on Engineering Education -The moving frontiers of engineering, Coimbra

Papaefthimiou, S., Syrrakou, E. \& Yianoulis, P. 2006. Energy performance assessment of an electrochromic window. Thin Solid Films 502, 257 - 264.

Pentland, A. 1996. Smart Rooms. Scientific American: 54-62.

Planck, J. 2005. Applications of Biopolymers in Construction Engineering. Biopolymers Online 29-39.

Plank, J. 2004. Application of biopolymers and other biotechnological products in building material. Applied Microbiology and Biotechnology, 66, 1-9.

Quapp, U. \& Holschemacher, K. 2013. Efforts to reduce the drop-out rate in civil and structural engineering programs. Research and Applications in Structural Engineering, Mechanics and Computation - Proceedings of the 5th International Conference on Structural Engineering, Mechanics and Computation, SEMC 2013, 2545-2548.

Rockström, J., W. Steffen, K. Noone, A. Persson, F. S. Chapin, III, E. Lambin, T. M. Lenton, M. Scheffer, C. Folke, H. Schellnhuber, B. Nykvist, C. A. De Wit, T. Hughes, S. van der Leeuw, H. Rodhe, S. Sörlin, P. K. Snyder, R. Costanza, U. Svedin, M. Falkenmark, L. Karlberg, R. W. Corell, V. J. Fabry, J. Hansen, B. Walker, D. Liverman, K. Richardson, P. Crutzen, \& J. Foley. 2009. Planetary boundaries:exploring the safe operating space for humanity. Ecology and Society 14(2): 32

Rothe, C. 2006. Using patents to advance the civil engineering profession. Civil Engineering 67-73.

Salcedo-Rahola, B. \& Mulder, K. (2009) European Sustainable Development Master Report. What has Europe got to offer? TU Delft

Santamouris, M., Synnefa, A. \& Karlessi, T. 2011. Using advanced cool materials in the urban built environment to mitigate heat islands and improve thermal comfort conditions. Solar Energy 85, 3085-3102.

Van Hoof, J., Aarts, M., Rense, C. \& Schoutens, A. 2009. Ambient bright light in dementia: effects on behaviour and circadian rhythmicity. Building and Environment 44(1):14655.

Waheed, B., Khan, F., Veitch, B. \& Hawboldt, K. 2011. An integrated decision-making framework for sustainability assessment: A case study of memorial University. Higher Education Policy, 24 (4), 481-498.

United Nations (2015) World population prospects: The 2015 revision. . Department of Social Affairs, population Division.

Wong, J., Li, H. \& Wang, S. 2005. "Intelligent building research: a review", Automation in Construction, Vol. 14 No. 1, pp. 143-159.

Zheng, W., Shih, H., Lozano, K. \& Mo, Y. (2011) Impact of nanotechnology on future civil engineering practice and its reflection in current civil engineering education. J. Prof. Issues Eng. Educ. Pract., 137(3), 162-173. 